\title{
LETHAL EFFECTS OF ULTRAVIOLET RADIATION UNDER DIFFERENT CONCENTRATIONS OF DISSOLVED ORGANIC CARBON ON NEOBOSMINA CHILENSIS (DADAY, 1902) (CLADOCERA, BOSMINIDAE)
}

\author{
BY \\ PATRICIO DE LOS RÍOS ${ }^{1}$ ) \\ Universidad Católica de Temuco, Facultad de Ciencias, \\ Departamento de Ciencias Biológicas y Químicas, Casilla 15-D, Temuco, Chile
}

\begin{abstract}
The increase in the penetration of ultraviolet radiation that has been reported lately for freshwater ecosystems in southern South America, would allegedly generate alterations in ecological processes. In the present study, the mortality of Neobosmina chilensis (Daday 1902), a small cladoceran distributed in South American lakes and ponds, was studied in this respect. Specimens were reared in five different concentrations of dissolved organic carbon, and subjected to $24 \mathrm{hrs}$ of exposure to artificial ultraviolet radiation.

An inverse correlation between the dissolved organic carbon concentration and individual mortality was found. This result supports the description of a screen effect of dissolved organic carbon against ultraviolet radiation. The data obtained describe a linear relation, in which $\mathrm{LC}_{50}$ corresponded to $4.43 \mathrm{mg} / \mathrm{l}$ of dissolved organic carbon. The ecological implications of this result are discussed.
\end{abstract}

\section{RESUMEN}

El incremento de la penetración de la radiación ultravioleta ha sido reportado para ecosistemas lacustres en el sur de Sudamérica, y genera alteraciones en procesos ecológicos. En el presente trabajo, se estudió la mortalidad de Neobosmina chilensis (Daday, 1902), un cladócero de pequeño tamaño corporal distribuido en lagos y lagunas de América del Sur. Los especímenes fueron mantenidos por 24 horas bajo cinco concentraciones de carbono orgánico disuelto, y con exposición a radiación ultravioleta artificial.

Se observó una relación inversa notoria entre la concentración de carbono orgánico disuelto y la mortalidad individual. Este resultado respalda la propuesta que el carbono orgánico disuelto genera un efecto protector contra la radiación ultravioleta. Los resultados describieron $\mathrm{LC}_{50}$ correspondió a $4.43 \mathrm{mg} / \mathrm{l}$ of carbono orgánico disuelto. Se discutieron las implicancias ecológicas de los resultados obtenidos.

1) e-mail: prios@uct.cl 


\section{INTRODUCTION}

In recent years, an increase in the penetration of ultraviolet radiation has been reported, caused by a decrease in atmospheric ozone. In South America, this situation was mainly studied for Patagonia (Cabrera et al., 1995; Villafañe et al., 2001) and for some mountain zones (Villafañe et al., 1999; Helbling et al., 2002). These changes in the penetration of ultraviolet radiation induced alterations in freshwater ecosystems, resulting in physiological changes in plankton organisms, which are partly reflected in protective and/or reparative responses (Hebert \& Emery, 1990; Villafañe et al., 2001). A natural protective resource against ultraviolet radiation is dissolved organic carbon, which is able to absorb different wave lengths within the ultraviolet spectrum (Morris et al., 1995), and which thus can act as a protective "screen" for the plankton (Williamson et al., 2001; Rautio \& Korkhola, 2002a, b; De los Ríos, 2003). This interaction between ultraviolet radiation and dissolved organic carbon can also have another positive effect, because it generates molecules that are used by bacteria, and these bacteria are again grazed upon by the zooplankton (Reche et al., 1998). On the other hand, it can also cause a negative effect, because this interaction would cause the production of peroxides and reactive oxygen substances unfavourable for zooplankton organisms (Reche et al., 1998).

The presence of shallow ponds with high concentrations of dissolved organic carbon had been reported for moutains lakes in northern Chile (De los Ríos, 2003), and southern Patagonia (Morris et al., 1995; De los Ríos, 2003), whereas, in contrast, in southern Patagonia there are also great lakes with a notoriously low level of dissolved organic carbon (Soto \& Campos, 1995; Morris et al., 1995; De los Ríos, 2003).

Crustacean zooplankters exhibit different responses to the exposure to ultraviolet radiation. Thus, in the deep and pristine lakes where there is a high penetration of ultraviolet light, the zooplankton makes vertical migrations to depth zones without ultraviolet radiation (Storz \& Paul, 1998; Rhode et al., 2001; Villafañe et al., 2001). One typical species from deep lakes and shallow ponds is Neobosmina chilensis (Daday, 1902), distributed mainly in Patagonia (Campos, 1984; Ruiz \& Bahamonde, 1989; Soto \& Zúñiga, 1991; De los Ríos, 2003). In the present study, the effectiveness of dissolved organic carbon, acting as a protective screen against ultraviolet radiation was determined experimentally, by monitoring, in different concentrations, the survival of $N$. chilensis.

\section{MATERIAL AND METHODS}

The experiment was done in the Photobiology Laboratory of the Comahue National University in Bariloche, southern Argentina. A water sample with a high 
TABLE I

Dissolved organic carbon (DOC) concentrations and absorption coefficients for different wave lengths within the ultraviolet spectrum as observed for the lakes Escondido and Gutierrez (from: Morris et al., 1995: 1385)

\begin{tabular}{lcccccc}
\hline Site & $\mathrm{mg} / \mathrm{l}$ DOC & $\mathrm{A}_{305}$ & $\mathrm{~A}_{320}$ & $\mathrm{~A}_{340}$ & $\mathrm{~A}_{380}$ & $\mathrm{~A}_{440}$ \\
\hline Escondido Lake & 2.66 & 7.32 & 6.47 & 4.51 & 1.91 & 0.67 \\
Gutierrez Lake & 0.32 & 0.32 & 0.71 & 0.60 & 0.46 & 0.11 \\
\hline
\end{tabular}

concentration of dissolved organic carbon was collected in Escondido lake, and another water sample with low dissolved organic carbon was collected in the river Gutierrez, an effluent of the lake of the same name (table I; see also Morris et al., 1995). All samples were filtered at $60 \mu \mathrm{m}$ for the removal of rotifers and small planktonic crustaceans. The water of Escondido lake was used as the high concentration, and was used after mixing with the water from Gutierrez river, at dilutions of $75 \%, 50 \%, 25 \%$, and $1 \%$ (table I). Both sites have similar trophic and chemical characteristics (Pedrozo et al., 1993). Thus, an experimental design in triplicate was set up.

The experiment was done in 12 quartz tubes of $40 \mathrm{ml}, 15 \mathrm{~mm}$ inner diameter, which were exposed to ultraviolet light from a fluorescent lamp "Spectroline XX15-B" (Spectronic Corporation). This lamp was covered with a diacetate cellulose plate that removed wavelengths below $295 \mathrm{~nm}$, and was installed at a distance of $40 \mathrm{~cm}$ from the experimental units. The light included in the visible spectrum came from two $120 \mathrm{~cm}$ fluorescent tubes (Philips daylight TLT 40W/54RS). The exposure to these radiation fractions would allegedly generate photoprotective responses against ultraviolet radiation (Zagarese et al., 1997). The illumination conditions were: $24 \mathrm{~h}$ light of visible radiation and 8 $\mathrm{h}$ of ultraviolet exposure at a constant temperature of $8^{\circ} \mathrm{C}$. The quartz tubes were filled with their corresponding solutions of different levels of dissolved organic carbon, and each one was inoculated with 20 live individuals. According to other, similar experiments (Zagarese et al., 1997), this density was deemed adequate to prevent density-dependent effects on the organisms. The experiment was set up at 18:00 hrs. and finished 24 hours later when dead individuals were counted per treatment. At the end of the experimental period, the individual mortality in each treatment was thus established, and a regression analysis was applied to obtain the respective equations using the software package Statistica 5.0. Finally, the $\mathrm{LC}_{50}$ value (lethal concentration of $50 \%$ mortality) was estimated. 


\section{TABLE II}

Results in percentage of average mortality \pm standard error, obtained in the experiment with Neobosmina chilensis (Daday, 1902) described in the present study

\begin{tabular}{ccr}
\hline $\mathrm{mg} / \mathrm{l}$ DOC & \% Dilution & \% Mortality \\
\hline 2.66 & 100 & $63.3 \pm 6.0$ \\
2.00 & 75 & $81.7 \pm 1.7$ \\
1.33 & 50 & $98.3 \pm 1.7$ \\
0.67 & 25 & $100.0 \pm 0.0$ \\
0.02 & 1 & $100.0 \pm 0.0$ \\
\hline
\end{tabular}

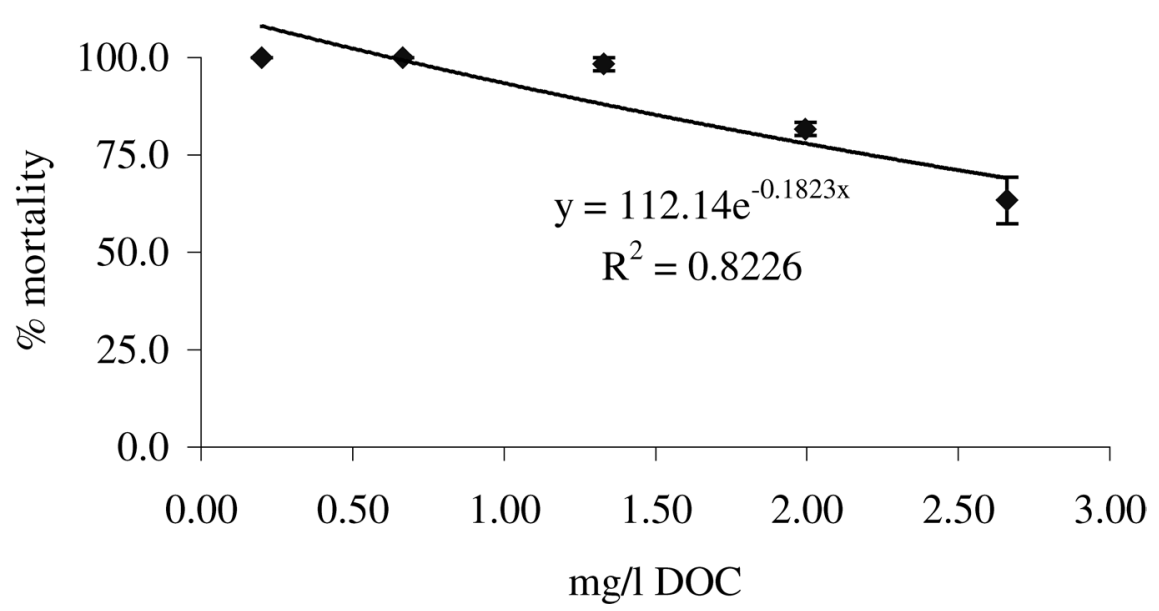

Fig. 1. Results of the mortality of Neobosmina chilensis (Daday, 1902), under UV radiation in relation to the dissolved organic carbon concentration, as observed in the present study.

\section{RESULTS AND DISCUSSION}

The results obtained reveal a direct correlation between the mortality of Neobosmina chilensis as a result of ultraviolet radiation and dissolved organic carbon (table II, fig. 1), i.e., a linear trend. The absolute mortality was high, which indicates that this species is very sensitive to exposure to ultraviolet radiation. The $\mathrm{LC}_{50}$ observed was at $4.43 \mathrm{mg} / \mathrm{l}$ dissolved organic carbon. Although there was a high absolute mortality, the direct relation observed between dissolved organic carbon and absolute mortality indicates that this component of the water is an important protective resource against ultraviolet radiation for $N$. chilensis.

The results reveal an inverse correlation between mortality and the dissolved organic carbon concentration under conditions of exposure to ultraviolet radiation, and are similar to those obtained for cladocerans of the genus Daphnia in the 
northern hemisphere (Williamson et al., 2001). Species of Daphnia are dominant in the zooplankton of the lakes on the northern hemisphere (Gillooly \& Dodson, 2000), whereas the zooplankton in lakes of southern South America is mainly characterized by a dominance of calanoid copepods and small cladocerans, such as N. chilensis (cf. Soto \& Zúñiga, 1991; Zagarese et al., 1998; Gillooly \& Dodson, 2000). This zooplankton assemblage is frequently found, in many lakes and ponds, whence it is possible that this assemblage is in fact part of the primary biocoenosis in large and deep lakes as well as in shallow, small ponds (De los Ríos, 2003).

The presence of the genus Neobosmina in these differing groups of freshwater ecosystems would indicate that each population would generate different responses to the exposure to ultraviolet radiation. Thus, for instance, the zooplankton assemblage of a great lake with high transparency of the water column, is quite vulnerable to exposure to ultraviolet radiation (Tartarotti et al., 1999, 2000), and would develop vertical migrations to zones where the ultraviolet radiation does not penetrate (Van Gool, 1998; Leech \& Williamson, 2000, 2001; Vareschi \& Wübben, 2001; Villafañe et al. 2001). Also, in shallow ponds, it is possible that the dissolved organic carbon would cause a protective effect against ultraviolet radiation (De los Ríos, 2003), which is supported by the results obtained in the present study (table II, fig. 1).

\section{ACKNOWLEDGEMENTS}

This study was funded by project IAI (Enhanced Ultraviolet B Radiation in Natural Ecosystems as an Added Perturbation Due to Ozone Depletion), the Research Direction of the Catholic University of Temuco, CONICYT (scholarship supporting doctorate thesis), the Research and Development Direction (Project DID-UACH D2001-11), and the Graduate School of the Faculty of Science of the Austral University of Chile. The experiment was carried out at the Photobiology Laboratory, Universidad Nacional del Comahue (Centro Regional Universitario Bariloche), headed by Dr. Horacio Zagarese, and his staff, whom we want to express our gratitude for their professional and personal support.

\section{REFERENCES}

Cabrera, S., S. Bozzo \& H. Fuenzalida, 1995. Variations in UV radiation in Chile. Journal of Photochemistry and Photobiology, (B, Biology) 28: 137-142.

CAmpos, H., 1984. Limnological study of Araucanian lakes (Chile). Verhandlungen der Internationale Vereinigung für Theoretische und Angewandte Limnologie, 22: 1319-1327.

DE LOS Ríos, P., 2003. Efectos de las disponibilidades de recursos energéticos, estructurales y de protección sobre la distribución y abundancia de copépodos y cladóceros zooplanctónicos 
lacustres chilenos: 1-107. (Doctoral Thesis, Austral University of Chile, Science Faculty, Valdivia, Chile). [In Spanish with English abstract.]

Gillooly, J. F. \& S. I. Dodson, 2000. Latitudinal patterns in the size distribution and seasonal dynamics of new world, freshwater cladocerans. Limnology and Oceanography, 45: 22-30.

Gool, E. VAN, 1998. Diel vertical migration of Daphnia: an inquiry into mechanisms of phototactic behaviour: 1-117. (Doctoral Thesis, Universiteit van Amsterdam, Amsterdam).

Hebert, P. D. N. \& C. J. EMERY, 1990. The adaptative significance of cuticular pigmentation in Daphnia. Functional Ecology, 4: 703-710.

Helbling, E. W., F. Zaratti, L. O. Sala, E. R. Palenque, C. F. Menchim \& V. E. VILLAFAÑE, 2002. Mycosporine-like amino acids protect the copepod Boeckella titicacae (Harding) against high levels of solar UVR. Journal of Plankton Research, 24: 225-234.

LEECH, D. M. \& C. E. WILLIAMSON, 2000. Is tolerance to UV radiation in zooplankton related to body size, taxon, or lake transparency? Ecological Applications, 10: 1530-1540.

— — \& _ _ 2001. In situ exposure to ultraviolet radiation alters the depth distribution of Daphnia. Limnology and Oceanography, 46: 416-420.

Morris, D. P., H. E. Zagarese, C. E. Williamson, E. G. Balseiro, B. R. Hargreaves, B. E. Modenutti, R. E. Moeller \& C. P. Queimaliños, 1995. The attenuation of solar UV radiation in lakes and the role of dissolved organic carbon. Limnology and Oceanography, 40: $1381-1391$.

Pedrozo, F., S. Chillrud, P. Temporetti \& M. Díaz, 1993. Chemical composition and nutrient limitation in rivers and lakes of northern Patagonian Andes (39.5' 42" S; $71 \mathrm{~W}$ ) (Rep. Argentina). Verhandlungen der Internationale Vereinigung für Theoretische und Angewandte Limnologie, 25: 207-214.

Rautio, M. \& A. Kor Khola, 2002a. UV-induced pigmentation in subarctic Daphnia. Limnology and Oceanography, 47: 295-299.

— _ \& _ - 2002b. Effects of ultraviolet radiation and dissolved organic carbon on the survival of subarctic zooplankton. Polar Biology, 25: 460-468.

RECHE, I., M. L. PACE \& J. J. COLE, 1998. Interactions of photobleaching and inorganic nutrients in determining bacterial growth on colored dissolved organic carbon. Microbial Ecology, 36: 270-280.

RhoDe, S. C., M. PAWlowski \& R. TOllRian, 2001. The impact of ultraviolet radiation on the vertical distribution of zooplankton of the genus Daphnia. Nature, London, 412: 69-72.

Ruiz, R. \& N. BAHAMONDE, 1989. Cladóceros y copépodos limnicos en Chile y su distribución geográfica. Lista sistematica. Publicación Ocacional Museo Nacional de Historia Natural, Santiago de Chile, 45: 1-48. [In Spanish.]

Soto, D. \& H. Campos, 1995. Los lagos oligotróficos del bosque templado húmedo del sur de Chile. In: J. Armesto, M. Khalin \& M. Villagrán (eds.), Ecología del bosque Chileno: 134-148. (Editorial Universitaria, Santiago de Chile). [In Spanish.]

Soto, D. \& L. ZÚÑIGA, 1991. Zooplankton assemblages of Chilean temperate lakes: a comparison with North American counterparts. Revista Chilena de Historia Natural, 64: 569-581.

Storz, U. C. \& R. J. PAul, 1998. Phototaxis in water fleas (Daphnia magna) is differently influenced by visible and UV light. Journal of Comparative Physiology, (A) 183: 709-717.

TArtarotti, B., W. Cravero \& H. E. Zagarese, 2000. Biological weighting function for the mortality of Boeckella gracilipes (Copepoda: Crustacea) derived from experiments with natural solar radiation. Photochemistry and Photobiology, 72: 314-319.

TARTARotTi, B., S. CABrera, R. PSEnNer \& R. SommarUGA, 1999. Survivorship of Cyclops abyssorum tatricus (Cyclopoida, Copepoda) and Boeckella gracilipes (Calanoida, Copepoda) under ambient levels of solar UVB radiation in two high-mountain lakes. Journal of Plankton Research, 21: 549-560. 
VARESChI, E. \& D. WÜBben, 2001. Vertical migration of Daphnia pulex in response to UV radiation. Verhandlungen der Internationale Vereinigung für Theoretische und Angewandte Limnologie, 27: 3349-3353.

Villafañe, V. E., M. Andrade, V. Lairana, F. Zaratti \& E. W. Helbling, 1999. Inhibition of phytoplankton photosynthesis by solar ultraviolet radiation: studies in lake Titicaca, Bolivia. Freshwater Biology, 42: 215-224.

Vill Afañe, V. E., E. W. Helbling \& H. E. ZaGARESE, 2001. Solar ultraviolet radiation and its impact on aquatic ecosystems of Patagonia, South America. Ambio, 30:112-117.

Williamson, C. E., S. Olson, S. E. Lott, N. D. Walker, D. R. Engstrom \& B. R. HARGREAVES, 2001. Ultraviolet radiation and zooplankton following deglaciation in Glacier Bay, Alaska. Ecology, 82: 1748-1760.

Zagarese, H. E., M. Díaz, F. Pedrozo \& M. Ubeda, 1998. Mountain lakes in northwestern Patagonia. Verhandlungen der Internationale Vereinigung für Theoretische und Angewandte Limnologie, 27: 533-538.

Zagarese, H. E., M. Feldman \& C. E. Williamson, 1997. UV-B-induced damage and photoreactivation in three species of Boeckella (Copepoda: Calanoida). Journal of Plankton Research, 19: 357-367. 